JMKSP (Jurnal Manajemen, Kepemimpinan, dan Supervisi Pendidikan)

Volume 6 Issue 2 (2021) Page 336-351

ISSN 2614-8021 (Online) 2548-7094 (Print)

\title{
A Study of Student Learning Attitude Towards E-Learning In The Pandemic Era
}

\author{
Direstu Amalia ${ }^{1}$, Wildan Nugraha ${ }^{2}$ \\ ${ }^{1,2}$ Politeknik Penerbangan Palembang \\ Corresponding Author E-mail: direstu@poltekbangplg.ac.id
}

Received 15 June 2021; Revised 20 June 2021; Accepted 25 June 2021

\begin{abstract}
This study aims to examine student learning attitudes towards e-learning as a learning medium in the pandemic era. This research begins with a survey as input for a quantitative approach. The collected data was then analysed and checked for validation using Pearson's correlation. The results showed that students were ready for class changes from face-to-face to e-learning and considered that elearning was better in terms of presenting materials and assignments. $82 \%$ of students consider Online learning ensures the effectiveness for presenting the work in class. $62 \%$ of them respond to adjustments and mastery of technology and applications on computers and the internet can be handled properly so that it can be said that students have good digital competence. However, $50 \%$ of students still prefer face-to-face classes to virtual classes because they think face-to-face classes are better in interacting with teachers and friends.
\end{abstract}

Keyword: E-learning, Student Learning Attitude, Digital Competence,

\section{Introduction}

E-Learning support learning from home

The Covid-19 pandemic has impacted the Indonesian economy (Suryan, Sari, Amalia, \& Habillah, 2020) and affected almost all industrial sectors (Nugraha \& Amalia, 2021). In response to the Covid-19 pandemic, all campuses have 
switched from face-to-face into online learning activities through various media. The availability of good online learning facilities which provides convenience and motivation to students. Teachers must be able to find the right method so that students are able to adapt and optimize in online learning (Coman, Gabriel, Meses, Stanciu, \& Cristina Bularca, n.d.). The availability of adequate technology and internet is the most important role in this online learning (Elnasr, Sobaih, Hasanein, \& Elnasr, n.d.). The existence of the Learning Management System (LMS), as well as other supporting media such as WhatsApp, Zoom, Google are becoming "heroes" in the era of learning from home.

\section{Independent Learning and Student Learning Attitude}

In the online learning environment, there are two most influential factors, namely technology and creativity. The situation for online classes is very different from traditional classes. Interaction has changed to a virtual model with a synchronous and asynchronous learning model (Yang \& Cornelious, n.d.) (Handayani \& Sudiyana, 2015) and the students need to adapt to this situation if they want to succeed in learning. Students who usually accept and become passive in face-to-face classes, need to be creative in finding learning resources and be active in virtual discussions. Students must immediately identify their own readiness, their learning style, and what they have achieved in learning what we call independent learners (Goode, 2007) (Khan, and, \& 2019, n.d.). According to (Caravello, ..., \& 2020, n.d.) (Gross, 1977)students must have skills, knowledge and abilities in using computers called digital competencies to support their independence in learning. Independent learners are students who are able to take responsibility for what they learn on their own. It takes initiative and the ability to make the right decisions without direct teacher guidance (Goode, 2007). Technology and teachers are needed in producing independent learners where students are able to improve their academic performance and motivation independently.

This change in learning model results in changes not only in educational institutions, but also in student attitudes, the way students respond to them may be different from before the pandemic occurred. This study aims to capture students' 
attitudes towards e-learning include the use of technology and how their adapt to the situation.

\section{Literature Review}

\section{E-Learning and Student Digital Competence}

E-learning is a learning model that can reach (accessibility) through remote areas (Septiani, Amalia, Progressive, \& 2020, n.d.), it is expected lighter transportation factors and learning costs and lead to paperless so that it is quite affordable (affordability). Students can arrange their schedule when to work on assignments (flexibility). Accessible online learning content and user-friendly media involve the use of technology should standardize. The use of internet technology has succeeded in combining face-to-face learning with independent learning (mixed method) and flip class method so that it is expected to provide wider learning opportunities for students to develop new skills that lead to long-life learning methods. The world of education views it as important to become a new paradigm in the learning method.

A study related to providing empirical evidence that the ability of the generation of technology varies where the "Net-Generation" has put the highest level of digital competence (Khan et al., n.d.). Students push to have the ability to survive with the changes of technology including adjustment knowledge and skills we need for appropriately using ICT for our purposes, personally and professionals to achieve success e-learning.

Technology Acceptance Model (TAM) helps in providing an overview of the behavior of students while using information technology (Legris, Ingham, \& Collerette, 2003). Davis in 1989 express TAM as the basic protocol to define the attitude of user whether accept or reject the utilization of information technology. TAM provides a base with which the pattern of influencing confidence, attitudes, and plan of using the information technology in a specified duration of time can be observed and trailed. 


\section{Student Attitude as e-learning critical success factor}

Instructor, student, information technology, and university support (Selim, 2007) are the e-learning critical success factors (CSFs). Another research (Volery $\&$ Lord, 2000) states three CSF: technology including ease of access and ease of navigating, design of the interface and the level of interaction of student-teacherstudent; instructor (attitudes toward students, technical competence, and interaction); and student's perspective to the use of technology. To provide a pedagogical foundation as a basic requirement for the successful implementation of e-learning, the research of Govindasamy (Govindasamy, n.d.) discussed seven elearning quality benchmarks: support from the institution, development of the course, teaching and learning, course structure, student support, faculty support, evaluation and assessment. To achieve learning goals through e-learning, we must promise that CSF includes students. Students should capable to manage their time, discipline, and maintain their motivation. Yu \& Yang (S Yu, n.d.) conducted a quantitative study using a structured questionnaire to explore attitudes towards web-based distance learning and it's finding the feasibility and the new way of learning that trigger the positive attitudes of students. In another study, a survey focused on groups to determine student attitudes towards multimedia technology in online learning has shown very positive student attitudes (Kirkup \& Kirkwood, 2005).

\section{Methods}

This research is quantitative research with questionnaires. A closed questionnaire with a 4-Likert scale. Cadet of Politeknik Penerbangan Palembang was chosen as research location. Data were collected through a survey using google forms with 27 questions (Sugiyono, 2017). SPSS were used for processing the data and validation test using moment Pearson correlation. The literature study also obtains a piece of valid information related to the results of the research.

\section{Results and Discussion}

The results of this study are quantitative data from 3 main themes consisting of several questions with a total of 27 (twenty-seven) questions. The results will be 
described in the form of a description of the results per question of the 3 main themes. The total number of cadets is 120 (one hundred and twenty), and the data collected comes from 99 (ninety-nine) respondents with 30 (30.3\%) female respondents and $69(69.7 \%)$ male respondents. The total population shows that the number of students on this campus is dominated by male students.

\section{Table 1. Distibution of Respondent by Gender}

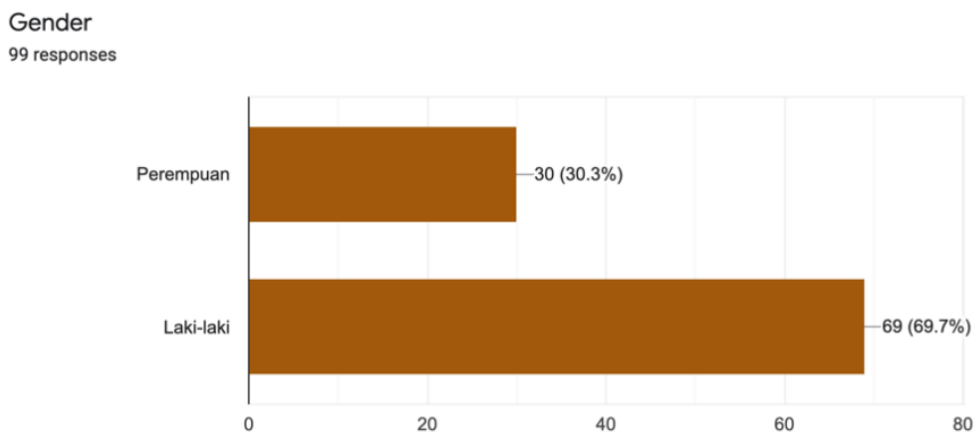

This study uses a question instrument from research related to student attitude towards online learning (Ullah, Khan, Sci, \& 2017, n.d.) by considering the similarity of goals and the concept of questions that are very representative of our research, in order to determine the correlation between students' interest in computers, usefulness of computer to students and ease in using online learning during the pandemic era.

\section{Validation of the results}

This study uses a survey method by distributing 27 questions in the form of a questionnaire consisting of 99 people as samples. To validate the questionnaire given to respondents or samples from the study. This validation uses the moment Pearson correlation validity test, which is a validity test that connects the score of each item to the total score of the respondents' answers. 
Table 2. $R_{\text {tabel }}$ Distribution Table (Significant $5 \%$ and 1\%)

\begin{tabular}{|c|c|c|c|c|c|}
\hline \multirow{2}{*}{$\mathrm{N}$} & \multicolumn{2}{|c|}{ The Level of Significance } & \multirow{2}{*}{$\mathrm{N}$} & \multicolumn{2}{|c|}{ The Level of Significance } \\
\hline & $5 \%$ & $1 \%$ & & $5 \%$ & $1 \%$ \\
\hline 3 & 0.997 & 0.999 & 38 & 0.320 & 0.413 \\
\hline 4 & 0.950 & 0.990 & 39 & 0.316 & 0.408 \\
\hline 5 & 0.878 & 0.959 & 40 & 0.312 & 0.403 \\
\hline 6 & 0.811 & 0.917 & 41 & 0.308 & 0.398 \\
\hline 7 & 0.754 & 0.874 & 42 & 0.304 & 0.393 \\
\hline 8 & 0.707 & 0.834 & 43 & 0.301 & 0.389 \\
\hline 9 & 0.666 & 0.798 & 44 & 0.297 & 0.384 \\
\hline 10 & 0.632 & 0.765 & 45 & 0.294 & 0.380 \\
\hline 11 & 0.602 & 0.735 & 46 & 0.291 & 0.376 \\
\hline 12 & 0.576 & 0.708 & 47 & 0.288 & 0.372 \\
\hline 13 & 0.553 & 0.684 & 48 & 0.284 & 0.368 \\
\hline 14 & 0.532 & 0.661 & 49 & 0.281 & 0.364 \\
\hline 15 & 0.514 & 0.641 & 50 & 0.279 & 0.361 \\
\hline 16 & 0.497 & 0.623 & 55 & 0.266 & 0.345 \\
\hline 17 & 0.482 & 0.606 & 60 & 0.254 & 0.330 \\
\hline 18 & 0.468 & 0.590 & 65 & 0.244 & 0.317 \\
\hline 19 & 0.456 & 0.575 & 70 & 0.235 & 0.306 \\
\hline 20 & 0.444 & 0.561 & 75 & 0.227 & 0.296 \\
\hline 21 & 0.433 & 0.549 & 80 & 0.220 & 0.286 \\
\hline 22 & 0.432 & 0.537 & 85 & 0.213 & 0.278 \\
\hline 23 & 0.413 & 0.526 & 90 & 0.207 & 0.267 \\
\hline 24 & 0.404 & 0.515 & 95 & 0.202 & 0.263 \\
\hline 25 & 0.396 & 0.505 & 100 & 0.195 & 0.256 \\
\hline 26 & 0.388 & 0.496 & 125 & 0.176 & 0.230 \\
\hline 27 & 0.381 & 0.487 & 150 & 0.159 & 0.210 \\
\hline 28 & 0.374 & 0.478 & 175 & 0.148 & 0.194 \\
\hline 29 & 0.367 & 0.470 & 200 & 0.138 & 0.181 \\
\hline 30 & 0.361 & 0.463 & 300 & 0.113 & 0.148 \\
\hline 31 & 0.355 & 0.456 & 400 & 0.098 & 0.128 \\
\hline 32 & 0.349 & 0.449 & 500 & 0.088 & 0.115 \\
\hline 33 & 0.344 & 0.442 & 600 & 0.080 & 0.105 \\
\hline 34 & 0.339 & 0.436 & 700 & 0.074 & 0.097 \\
\hline 35 & 0.334 & 0.430 & 800 & 0.070 & 0.091 \\
\hline 36 & 0.329 & 0.424 & 900 & 0.065 & 0.086 \\
\hline 37 & 0.325 & 0.418 & 1000 & 0.062 & 0.081 \\
\hline
\end{tabular}

The product moment pearson correlation test has the basis for making decisions in the following way: 
a. Comparing the calculated $r$ value with the $r$ table value, namely:

1. If the value of $r$ count $>r$ table, then the item is declared valid.

2. If the value of $r$ count $<r$ table, then the item is declared invalid.

b. Comparing the value of Sig. (2-tailed) with a probability of 0.05 , namely:

1. If the value of Sig. (2-tailed $<0.05$ and the Pearson correlation is positive, then the item is valid.

2. If the value of Sig. (2-tailed $<0.05$ and the Pearson correlation is negative, then the item is invalid.

3. If the value of Sig. (2-tailed) $>0.05$, then the item is invalid (Asriyati \& Harun, 2020).

The results of the questionnaire which were processed into SPSS obtained the following results:

Table 3. Output data from SPSS

\begin{tabular}{|c|c|c|c|}
\hline \multirow[b]{2}{*}{ Item } & \multicolumn{3}{|c|}{ TOTAL } \\
\hline & $\begin{array}{c}\text { Pearson } \\
\text { Correlation }\end{array}$ & $\begin{array}{c}\text { Sig. } \\
\text { (2-tailed) }\end{array}$ & $\mathrm{N}$ \\
\hline $\mathrm{X} 1$ & $.301^{* *}$ & .002 & 99 \\
\hline $\mathrm{X} 2$ & $.293^{* *}$ & .003 & 99 \\
\hline $\mathbf{X 3}$ & $.380^{* *}$ & .000 & 99 \\
\hline $\mathrm{X} 4$ & $.387^{* *}$ & .000 & $\overline{99}$ \\
\hline $\mathrm{X5}$ & $.376^{* *}$ & .000 & 99 \\
\hline X6 & $.483^{* *}$ & .000 & 99 \\
\hline $\mathrm{X} 7$ & $.485^{* *}$ & .000 & 99 \\
\hline Y1 & $.257^{*}$ & .010 & 99 \\
\hline Y2 & $.414^{* *}$ & .000 & 99 \\
\hline Y3 & $.468^{* *}$ & .000 & 99 \\
\hline Y4 & $.440^{* *}$ & .000 & 99 \\
\hline Y5 & $.354^{* *}$ & .000 & 99 \\
\hline Y6 & $.317^{* *}$ & .001 & 99 \\
\hline Y7 & $.495^{* *}$ & .000 & 99 \\
\hline Y8 & $.410^{* *}$ & .000 & 99 \\
\hline Y9 & .140 & .167 & 99 \\
\hline Y10 & $512^{* * *}$ & .000 & 99 \\
\hline $\mathbf{Z 1}$ & $.427^{* *}$ & .000 & 99 \\
\hline$\overline{Z 2}$ & $.457^{* *}$ & .000 & 99 \\
\hline $\mathbf{Z 3}$ & $.346^{* *}$ & .000 & 99 \\
\hline$\overline{Z 4}$ & $.339^{* *}$ & .001 & 99 \\
\hline $\mathbf{Z 5}$ & $.466^{* *}$ & .000 & 99 \\
\hline Z6 & $.411^{* *}$ & .000 & 99 \\
\hline$\overline{\mathrm{Z} 7}$ & .135 & .183 & 99 \\
\hline $\mathbf{Z 8}$ & $.332^{* *}$ & .001 & 99 \\
\hline $\mathbf{Z 9}$ & .080 & .433 & 99 \\
\hline Z10 & $.221^{*}$ & .028 & 99 \\
\hline TOTAL & 1 & & 99 \\
\hline
\end{tabular}


The number of samples in this study was 99 respondents so that based on table 5 , if $\mathrm{N}=99$ then $\mathrm{R}_{\text {table }} 5 \%$ is 0.195 .

The validity test on item X1 based on table 6 SPSS X1 output has an R count of 0.301 while the $\mathrm{R}$ table of 0.195 means that the Pearson correlation is declared positive. While Sig. (2-tailed) X1 is 0.002 where the value of Sig. (2-tailed $<0.05$, meaning that item $\mathrm{X} 1$ is declared valid.

$\mathrm{R}_{\text {count }}>\mathrm{R}_{\text {table }}=0.301>0.195$ (pearson correlation positive value)

Sig. (2-tailed) count $<0.05=0.002<0.005$

\section{Table 4. Validity test-Product Moment Pearson Correlation}

\begin{tabular}{|c|c|c|c|c|}
\hline & \multicolumn{3}{|c|}{ TOTAL } & \multirow[b]{2}{*}{ Statement } \\
\hline Item & $\begin{array}{c}R_{x y} \\
\text { (table 3) }\end{array}$ & $\begin{array}{c}\text { Sig. } \\
\text { (2-tailed) }\end{array}$ & $\begin{array}{l}\text { Rtabel } \\
\text { (table 2) }\end{array}$ & \\
\hline $\mathrm{X} 1$ & $.301^{\text {*** }}$ & .002 & 0.195 & Valid \\
\hline $\mathrm{X2}$ & $.293^{* *}$ & .003 & 0.195 & Valid \\
\hline $\mathbf{X 3}$ & $.380^{* * *}$ & .000 & 0.195 & Valid \\
\hline $\mathrm{X} 4$ & $.387^{* * *}$ & .000 & 0.195 & Valid \\
\hline $\mathrm{X5}$ & $.376^{* * *}$ & .000 & 0.195 & Valid \\
\hline X6 & $.483^{* * *}$ & .000 & 0.195 & Valid \\
\hline $\mathrm{X} 7$ & $.485^{* * *}$ & .000 & 0.195 & Valid \\
\hline Y1 & $.257^{*}$ & .001 & 0.195 & Valid \\
\hline Y2 & $.414^{* * *}$ & .000 & 0.195 & Valid \\
\hline Y3 & $.468^{* * *}$ & .000 & 0.195 & Valid \\
\hline Y4 & $.440^{\text {*** }}$ & .000 & 0.195 & Valid \\
\hline Y5 & $.354^{* * *}$ & .000 & 0.195 & Valid \\
\hline Y6 & $.317^{\text {*** }}$ & .001 & 0.195 & Valid \\
\hline Y7 & $.495^{* * *}$ & .000 & 0.195 & Valid \\
\hline Y8 & $.410^{* * *}$ & .000 & 0.195 & Valid \\
\hline Y9 & .140 & .167 & 0.195 & Tidak Valid \\
\hline Y10 & $.512^{* * *}$ & .000 & 0.195 & Valid \\
\hline$\overline{Z 1}$ & $.427^{\text {*** }}$ & .000 & 0.195 & Valid \\
\hline $\mathbf{Z 2}$ & $.457^{\text {*** }}$ & .000 & 0.195 & Valid \\
\hline $\mathbf{Z 3}$ & $.346^{* * *}$ & .000 & 0.195 & Valid \\
\hline$\overline{\mathrm{Z4}}$ & $.339^{* *}$ & .001 & 0.195 & Valid \\
\hline$\overline{Z 5}$ & $.466^{* * *}$ & .000 & 0.195 & Valid \\
\hline$\overline{Z 6}$ & $.411^{* * *}$ & .000 & 0.195 & Valid \\
\hline$\overline{Z 7}$ & .135 & .183 & 0.195 & Tidak Valid \\
\hline $\mathbf{Z 8}$ & $.332^{\text {*** }}$ & .001 & 0.195 & Valid \\
\hline $\mathbf{Z 9}$ & .080 & .433 & 0.195 & Tidak Valid \\
\hline Z10 & $.221^{*}$ & .028 & 0.195 & Tidak Valid \\
\hline TOTAL & 1 & & 0.195 & \\
\hline & & & & \\
\hline
\end{tabular}


Based on the validity test, all items on Theme 1-Interest in computer and adoption of online learning are declared valid. The results of the validity test show that item Y9 on Theme 2-Effectiveness in e-learning and items Z7, Z9, and Z10 on Theme 3-Easeness in using online learning are invalid so that the item is excluded and not used in analyzing student attitude towards further online learning. .

\section{Analysis of the respondent answer}

The survey consists of 3 themes: Theme 1-Interest in computer and adoption of online learning, Theme 2-Effectiveness in e-learning, Theme 3-Easeness in using online learning which is expected to provide guidance on student attitude towards online learning in the pandemic era.

Table 5. Respondent Results for Theme 1 (X)

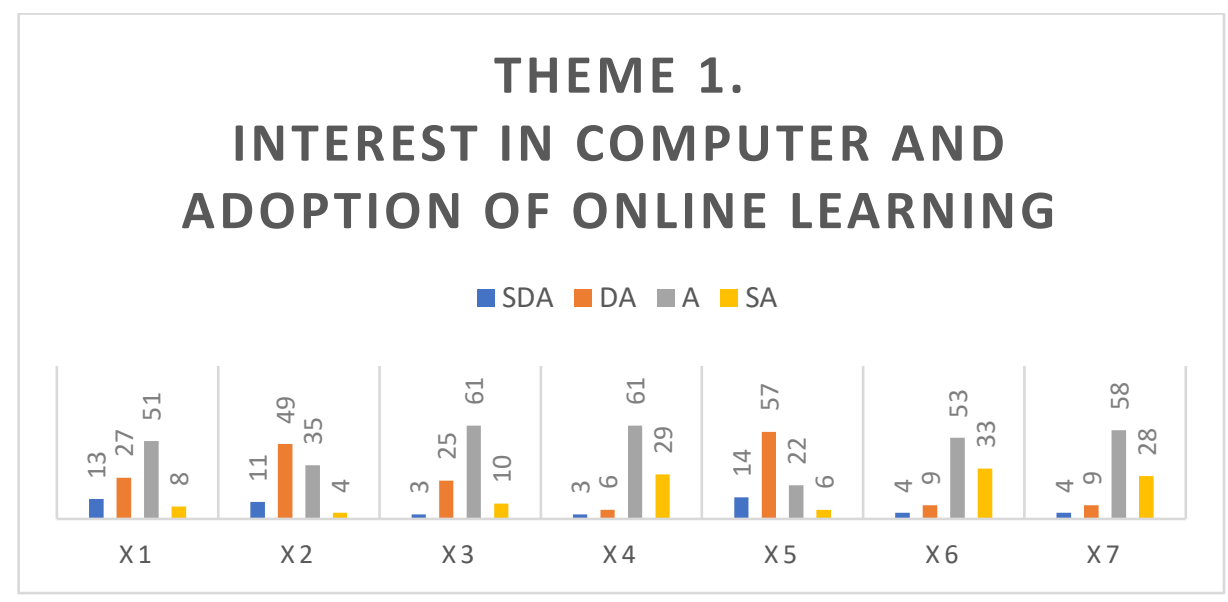

The first question (x1) as many as 51 (52\%) people answered "Agree (A)" to the question "It is difficult to understand online learning without getting acquainted with appropriate guidance".

The second question (x2) as many as 49 (50\%) people answered "Disagree (DA)" to the question "It is difficult to favor online learning on a regular basis due to least face to face interaction among students and teachers". 
The third question (x3) is $61(62 \%)$ "Agree (A)" on the question "Slow computer and poor internet connections discouraged to use online learning".

The fourth question (x4) as many as 61 (62\%) people "Agree (A)" on the question "As a useful programms suggested for peers to utilize online learning for online learning materials".

The fifth question (x5) as many as 57 (58\%) people "Disagree (DA)" on the question "Online learning is often avoided as it promotes social isolation". The sixth question (x6) as many as $53(54 \%)$ people "Agree (A)" on the question "Online learning highly motivates the students for taking advance courses".

The seventh question (x7) as many as $58(59 \%)$ people "Agree (A)" on the question "Using online learning makes learning interesting".

Table 6. Respondent Results for Theme 2 (Y)

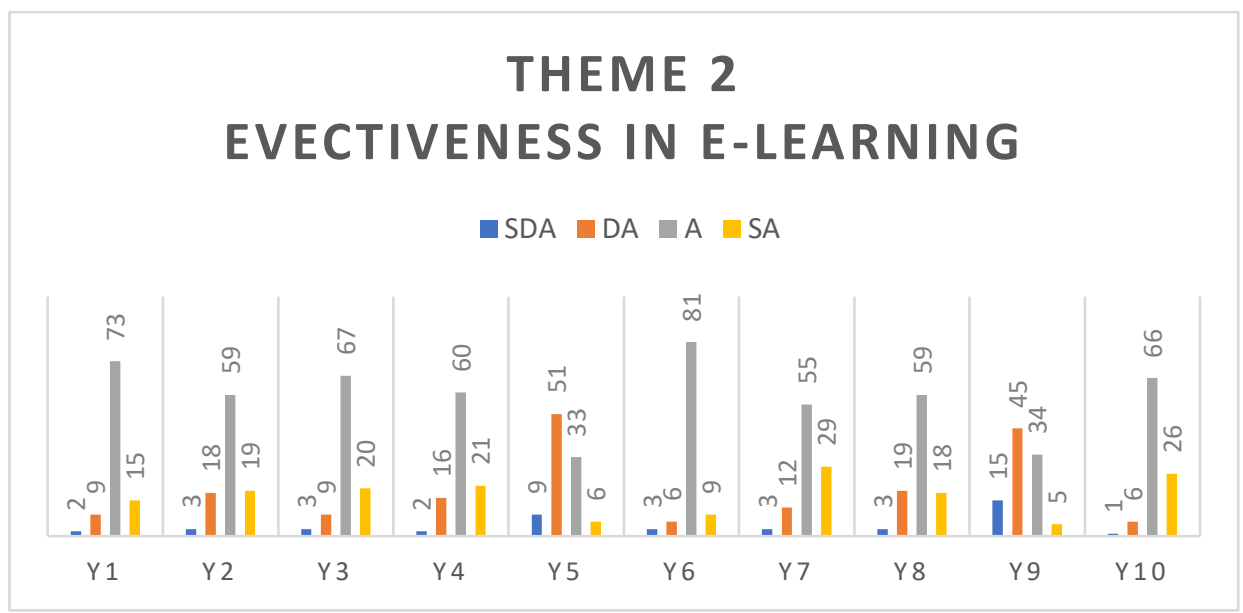

This second theme contains 10 (ten) questions that aim to determine the effectiveness of e-learning activities.

From the first question (Y1), 73 (74\%) people "Agree (A)" on the question "The usability and expertise in computer ensures the effectiveness in computer mediated learning". 
From the second question (Y2), 59 (60\%) people "Agree (A)" on the question "Online learning ensures the effectiveness in terms of coping up with missed lectures".

From the third question (Y3), 67 (68\%) people "Agree (A)" on the question "Productivity of students can be enhanced through online learning to strengthen educational concepts".

From the fourth question (Y4), 60 (61\%) people "Agree (A)" on the question "Online learning is economic in terms of time for students and teachers".

From the fifth question (Y5), 51 (52\%) people "Disagree (DA)" on the question "Student and teacher interaction is weak through online learning".

From the sixth question (Y6), $81(82 \%)$ people "Agree (A)" on the question "Online learning ensures the effectiveness for presenting the work in class".

From the seventh question (Y7) as many as $55(56 \%)$ people "Agree (A)" on the question "Quality of teaching and learning can be increased through Online learning because it integrates various types of media".

From the eighth question (Y8), 59 (60\%) people "Agree (A)" on the question "Online learning offers maximum engagement of students".

From the tenth question (Y10) as many as 66 (67\%) people "Agree (A)" on the question "Access to education increases through online learning". 
Table 7. Respondents Result in Theme 3 (Z)

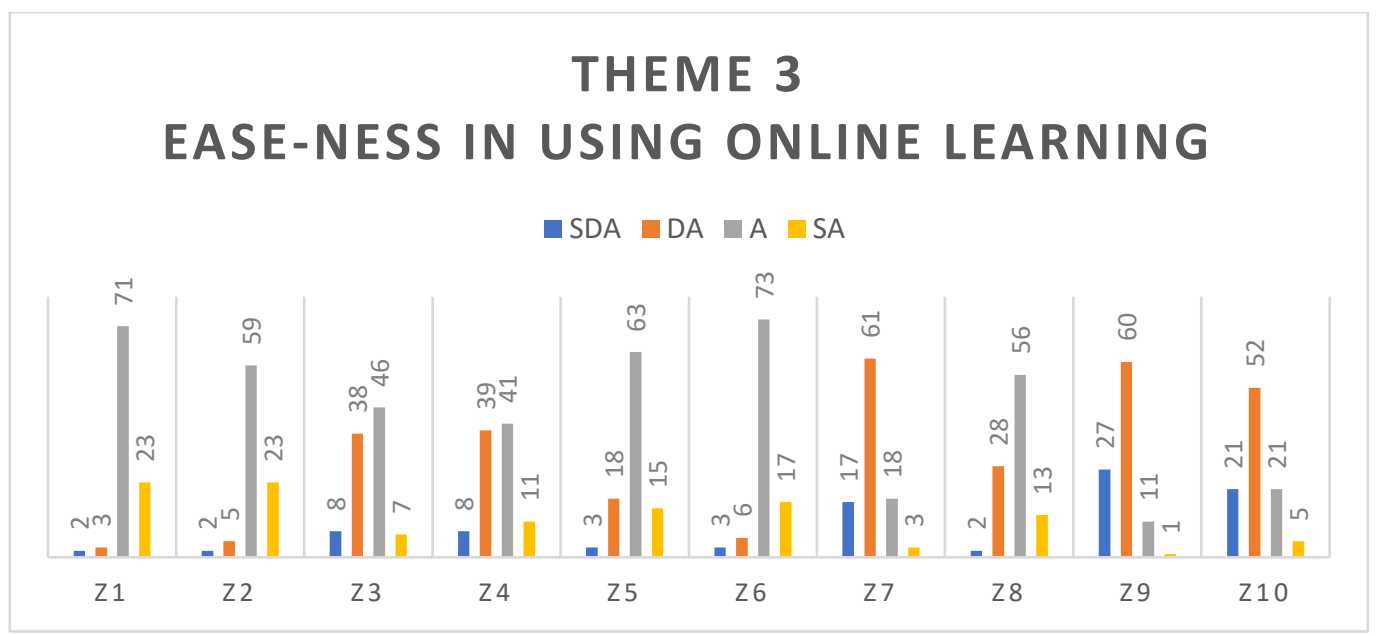

This third theme contains 10 (ten) questions that aim to determine the effectiveness of e-learning activities.

From the first question (Z1), 71 (72\%) people "Agree (A)" on the question "For searching online educational resources, the web is often student friendly".

From the second question (Z2), 69 (70\%) people "Agree (A)" on the question "Doing assignments and reading lecture's web notes are easy for students to manage and learn".

From the third question (Z3), 46 (47\%) people "Agree (A)" on the question "Expression of through and notions is a hectic job in terms of writing via online learning".

From the fourth question (Z4), 41 (42\%) people "Agree (A)" on the question "It is easy to read from print learning materials instead of electronic medium or internet".

From the fifth question (Z5), 63 (64\%) people "Agree (A)" on the question "Use of online learning is easier and better than using books/journals in the library". 
From the sixth question (Z6) as many as 73 (74\%) people "Agree (A)" on the question "It is easy to become skilled at using online learning system".

From the seventh question (Z7) as many as $61(62 \%)$ people "Disagree (DA)" on the question "Learning of courses through online portal is difficult".

\section{Conclusion}

From the results of the research above, it is known that in general, students are ready to change from face-to-face classes to online learning classes. The results of the analysis of the theme 1-Interest in computers and the application of online learning show that some respondents are not constrained by online learning but must be accompanied by proper guidance. Problems such as a slow computer, poor internet connection, and the need for a system support as a place to access the material. Respondents also agree that online learning does not create social isolation, respondents also feel interested in learning independently and find online learning interesting. The results of the analysis of theme 1 show a positive response which means there is a positive relationship between interest of students regarding computer and the level of student adaptation to online learning. This result is the same as that of (Pellas, 2014) (Gilakjani, 2012) and it is not the same as research (Ullah et al., n.d.) Which states that there is no significant relationship between the level of student interest in computers and the knowledge gained through online learning pembelajaran. In Theme 2-Effectiveness in e-learning respondents chose to agree that online learning needs to be supported by the ability to use technology, respondents believe that online learning is more effective due to factors such as: time efficiency, increased student productivity, ease of accessing subject matter. Online learning is also considered not to reduce student engagement and does not weaken the interaction between teachers and students. Similarly, the results of Theme 3-Easeness in using online learning respondents assessed that learning resources are widely available on many websites, they also consider it easier for students to manage and learn. Learning through online media is more acceptable to respondents than printed learning materials and they think online learning is not 
difficult, so it can be said that student attitudes towards the ease of using online learning are positive.

Finally, there are several recommendations made so that the implementation of online learning can run better: Design good training and improve the ability to use technology for students and teachers with workshops or seminars; The availability of easy-to-use online learning media that supports students' independent learning without eliminating social interaction and collaboration in learning (Fisher \& Baird, 2005); The motivation given by the teacher to the students; Availability of supporting infrastructure for online learning such as the internet and adequate computers.

\section{Acknowledgment}

I thank you for the ideas and input from colleagues, all respondents and all who have supported this research to completion. Thank you to my family for always supporting this research journey. I am blessed.

\section{References}

Asriyati, \& Harun, A. (2020). Analysis of Accounting Student Perceptions towards the Desire for a Career as Qualified Accountants: Case Study on Higher Education in Medan. Research Journal of Finance and Accounting Www.Iiste.Org ISSN, 11(2). https://doi.org/10.7176/RJFA/11-2-10

Caravello, M., C. H.-A. A. to B. (2020). Improving Teachers' Digital Competence to Bridge the Language Gap. Igi-Global.Com. Retrieved from https://www.igi-global.com/chapter/improving-teachers-digital-competenceto-bridge-the-language-gap/242298

Coman, C., Gabriel, iu T., Meses, L., Stanciu, C., \& Cristina Bularca, M. (n.d.). Online Teaching and Learning in Higher Education during the Coronavirus Pandemic: Students' Perspective. Mdpi.Com. https://doi.org/10.3390/su122410367

Elnasr, A., Sobaih, E., Hasanein, A. M., \& Elnasr, A. E. A. (n.d.). Responses to COVID-19 in Higher Education: Social Media Usage for Sustaining Formal Academic Communication in Developing Countries. Mdpi.Com. https://doi.org/10.3390/su12166520

Fisher, M., \& Baird, D. E. (2005). Online learning design that fosters student 
support, self-regulation, and retention. Campus-Wide Information Systems, 22(2), 88-107. https://doi.org/10.1108/10650740510587100

Gilakjani, A. P. (2012). The Significant Role of Multimedia in Motivating EFL Learners' Interest in English Language Learning. International Journal of Modern Education and Computer Science, 4(4), 57-66. https://doi.org/10.5815/ijmecs.2012.04.08

Goode, J. (2007). Empowering or disempowering the international Ph.D. student? Constructions of the dependent and independent learner. British Journal of Sociology of Education, 28(5), 589-603. https://doi.org/10.1080/01425690701505409

Govindasamy, T. (n.d.). Successful implementation of e-learning: Pedagogical considerations. Elsevier. Retrieved from https://www.sciencedirect.com/science/article/pii/S1096751601000719

Gross, R. (1977). The lifelong learner. Retrieved from https://eric.ed.gov/?id=ED178008

Handayani, T., \& Sudiyana. (2015). Analisis Penerapan Model UTAUT (Unified Theory Of Acceptance And Use Of Technology). Angkasa: Jurnal Ilmiah Bidang Teknologi, 7(2), 165-180. Retrieved from http://ejournals.stta.ac.id/index.php/angkasa/article/view/159

Khan, F., and, E. V.-I. J. of D. L., \& 2019, undefined. (n.d.). Digital Competence Assessment Across Generations: A Finnish Sample Using the Digcomp Framework. Igi-Global.Com. Retrieved from https://www.igiglobal.com/article/digital-competence-assessment-across-generations/236671 Kirkup, G., \& Kirkwood, A. (2005). Information and communications technologies (ICT) in higher education teaching - A tale of gradualism rather than revolotion. Learning, Media and Technology, 30(2), 185-199. https://doi.org/10.1080/17439880500093810

Legris, P., Ingham, J., \& Collerette, P. (2003). Why do people use information technology? A critical review of the technology acceptance model. Information and Management, 40(3), 191-204. https://doi.org/10.1016/S0378-7206(01)00143-4

Nugraha, W., \& Amalia, D. (2021). Covid-19 And Implementation of Airport Health and Safety Procedures: The Safety Culture Perception. Syntax Literate: Jurnal Ilmiah Indonesia, 6(4), 2070-2082. https://doi.org/10.36418/syntaxliterate.v6i4.2565

Pellas, N. (2014). The influence of computer self-efficacy, metacognitive self- 
regulation and self-esteem on student engagement in online learning programs: Evidence from the virtual world of Second Life. Computers in Human Behavior, 35, 157-170. https://doi.org/10.1016/j.chb.2014.02.048

$\mathrm{S} \mathrm{Yu,} \mathrm{K.} \mathrm{Y.} \mathrm{(n.d.).} \mathrm{Attitudes} \mathrm{toward} \mathrm{web-based} \mathrm{distance} \mathrm{learning} \mathrm{among} \mathrm{public}$ health nurses in Taiwan: A questionnaire survey. Elsevier. Retrieved from https://www.sciencedirect.com/science/article/pii/S0020748905001719

Selim, H. M. (2007). Critical success factors for e-learning acceptance: ConWrmatory factor models. Computers \& Education, 49, 396-413. https://doi.org/10.1016/j.compedu.2005.09.004

Septiani, V., Amalia, D., Progressive, D. C.-I. J. of, \& 2020, undefined. (n.d.). Implementation of Inspector Training System Certification Learning Based On E-Learning in Palembang Aviation Polytechnic. Ijpsat.Es. Retrieved from http://ijpsat.es/index.php/ijpsat/article/view/2271

Sugiyono. (2017). metodelogi penelitian kualitatif. Bandung: Alfabeta.

Suryan, V., Sari, A. N., Amalia, D., \& Habillah, M. F. (2020). Econometric Forecasting models for Air Freight in Indonesia (And How Will It be Affected by COVID-19?). Journal of Airport Engineering Technology (JAET), 1(1), 30-33. https://doi.org/10.52989/jaet.v1i1.5

Ullah, O., Khan, W., Sci, A. K.-P.-H. S., \& 2017, undefined. (n.d.). Students' attitude towards online learning at tertiary level. Academia.Edu. Retrieved from https://www.academia.edu/download/55550632/PUTAJ_2017.pdf

Volery, T., \& Lord, D. (2000). Critical success factors in online education. International Journal of Educational Management, 14(5), 216-223. https://doi.org/10.1108/09513540010344731

Yang, Y., \& Cornelious, L. F. (n.d.). Ensuring Quality in Online Education Instruction: What Instructors Should Know? Background of the problem. In ERIC. Retrieved from https://eric.ed.gov/?id=ED484990 